\title{
PENGARUH PENERAPAN KNOWLEDGE MANAGEMENT (KM) TERHADAP KESUKSESAN PENGADAAN SISTEM INFORMASI: PENDEKATAN KUANTITATIF
}

\section{THE IMPACT OF KNOWLEDGE MANAGEMENT PRACTICES ON INFORMATION SYSTEM OUTSOURCING: A QUANTITATIVE APPROACH}

\author{
${ }^{1}$ Asti Amalia Nur Fajrillah, ${ }^{2}$ R. Wahjoe Witjaksono \\ ${ }^{1,2}$ Program Studi Sistem Informasi, Fakultas Rekayasa Industri, Telkom University \\ 1astiamalia@telkomuniversity.ac.id, ${ }^{2}$ rwahyuwicaksono@ gmail.com
}

\begin{abstract}
Abstrak - Alih daya (outsourcing) sistem informasi atau sering kali disebut sebagai pengadaan sistem informasi dapat diartikan sebagai pengalihan sebagian atau seluruh fungsi sistem informasi dari sebuah organisasi kepada penyedia layanan eksternal, untuk memperoleh keuntungan ekonomi, teknologi dan strategis. Namun mendapatkan keuntungan dari outsourcing sistem informasi bukanlah hal yang mudah; terdapat beberapa faktor yang harus diperhatikan untuk mendapatkan keseluruhan keuntungan dari outsourcing sistem informasi, sehingga suatu organisasi dapat dikatakan berhasil dalam outsourcing sistem informasinya. Di lain pihak, penerapan Knowledge Management (KM) diartikan sebagai sebuah proses dari knowledge management yang disebut siklus pengetahuan (knowledge cycle), dimana terdapat kegiatan pembuatan (creation), penyebaran (sharing), dan penggunaan (application) pengetahuan didalamnya. Pada kebanyakan organisasi, KM dianggap sebagai faktor utama untuk memperoleh dan mendukung keunggulan bersaing. Selanjutnya, pengetahuan juga dianggap sebagai faktor yang sangat penting dalam keberhasilan outsourcing sistem informasi. Penelitian ini bertujuan untuk menguji hubungan antara penerapan Knowledge Management (knowledge creation, knowledge sharing, dan knowledge application) pada keberhasilan outsourcing sistem informasi melalui faktor penentu pengadaan sistem informasi (kualitas komunikasi dan kualitas kerjasama). Penelitian ini menggunakan metode kuantitatif dengan melibatkan 66 manajer proyek sistem informasi pada sektor telekomunikasi di Indonesia. Hasil menunjukkan bahwa knowledge application sebagai tahap akhir pada penerapan KM memberikan pengaruh signifikan terhadap kesuksesan outsourcing sistem informasi melalui kualitas komunikasi dan kualitas kerjasama. Pada akhirnya, menyediakan model penerapan knowledge management dapat digunakan sebagai salah satu panduan bagi organisasi dalam melakukan outsourcing sistem informasi untuk mencapai kesuksesan dan memperoleh keseluruhan keuntungan dari outsorcing sistem informasi tersebut.
\end{abstract}

Kata kunci: Knowledge Management, Knowledge Application, Outsourcing Sistem Informasi, Kualitas Komunikasi, Kualitas Kerjasama

$\begin{array}{ll}\text { Sejarah artikel } & \\ \text { Diterima redaksi: } & : 09 \text { Oktober } 2017 \\ \text { Revisi akhir } & : 03 \text { November } 2017 \\ \text { Diterbitkan online } & : \text { :08 Desember } 2017\end{array}$

Abstract-Information System (IS) outsourcing can be defined as turning over part or all of an organization's IS functions to external service provider, to acquire economic, technological, and strategic advantage. In regards on cost-effective access to specialized computing power or system development skill, outsourcing has become an important option for organization around the world. But, it is not easy to achieve goals in IS outsourcing; there are factors that need to take to achieved the overall organizational advantage obtained from IS outsourcing so that one organization can categorized its IS outsourcing conducted as success. In particular, Knowledge Management (KM) practices defined as the process of knowledge management called knowledge cycle which includes the activities of creation, sharing and application of knowledge. In many organizations, KM is seen as a key factor to gain and sustain competitive advantage. Furthermore, knowledge is seen as crucial factors in IS outsourcing success. This study aims to examine the relationship of knowledge management practices (knowledge creation, knowledge sharing, and knowledge application) on IS outsourcing success through IS outsourcing determinants (communication quality and partnership quality). This study used quantitative research methodology by participating 66 projects managers in Indonesian Telecommunication sector. The results revealed knowledge application as the last phase in knowledge management practices have significantly affect IS outsourcing success through communication quality and partnership quality as IS outsourcing determinants. Finally, providing knowledge management practices model can be used as guidance by those organizations which conduct IS outsourcing to achieve IS outsourcing success and to obtain the overall organizational advantage from IS outsourcing.

Keywords: Knowledge Management, IS Outsourcing, Communication Quality, Partnership Quality

\section{PENDAHULUAN}

Sejak tahun 1990-an outsourcing selalu menjadi tren dalam cepatnya perubahan lingkungan bisnis [1]. Alih daya (outsourcing) adalah kondisi dimana suatu organisasi memperoleh barang dan/atau layanan dari luar organisasi, kata pengadaan sering kali digunakan untuk outsourcing di tingkat pemerintahan [2]. Sehubungan dengan upaya terhadap effektifitas biaya bagi pengkhususan kemampuan komputasi atau kemampuan pengembangan sistem, outsourcing 
menjadi salah satu pilihan penting bagi organisasi di seluruh dunia [3]. Menurut outsourcing statistic dari "Information Technology Association of America (ITAA)", pengeluaran terhadap sumber global dari perangkat lunak dan layanan computer meningkat dari \$15 juta di tahun 2005 ke \$38 juta di tahun 2010 dan diperkirakan akan terus meningkat setiap tahunnya sebesar $20 \%$.

Ketika outsourcing dianggap sebagai pilihan strategis dan ekonomis yang baik dalam meningkatkan kinerja organisasi, pertumbuhan outsourcing proyek sistem informasi juga meningkat. Tidak hanya mengurangi pengeluaran tetap dan pengeluaran rutin, proyek outsourcing memungkinkan organisasi klien untuk fokus terhadap bisnis utama, memperoleh akses ke keterampilan dan teknologi tertentu, memberikan fleksibilitas, dan tentunya meningkatkan akuntabilitas [2], [4]. Outsourcing sistem informasi dapat diartikan sebagai pengalihan sebagian atau seluruhnya fungsi sistem informasi dari sebuah organisasi kepada penyedia layanan eksternal, untuk memperoleh keuntungan ekonomi, teknologi dan strategis [5].

Meskipun banyak keuntungan yang diperoleh dari proyek outsourcing, namun masih terdapat masalah besar mengenai penerapan outsourcing. Aberdeen Group melaporkan bahwa hampir $50 \%$ proyek outsourcing mengalami kegagalan baik secara keseluruhan ataupun kegagalan dalam memenuhi harapan. Terdapat beberapa penyebab dari tren kegagalan pada proyek outsourcing diantaranya akibat kurangnya komunikasi, adanya kesenjangan pengetahuan, dan ketidakmampuan organisasi dalam mengelola kerjasama dengan penyedia layanan. Pada akhirnya, organisasi yang melakukan outsourcing masih menghadapi tantangan.

Penelitian ini menyajikan empirical study dalam menguji hubungan penerapan knowledge management pada kesuksesan proyek outsourcing sistem informasi. Selain itu, penelitian ini berupaya untuk menyelidiki apakah penerapan knowledge management tersebut dapat mempengaruhi komunikasi dan kualitas kerjasama sebagai penentu outsourcing sistem informasi untuk memastikan keberhasilan proyek outsourcing sistem informasi berdasarkan perspektif dari organisasi klien.

\section{STUDI LITERATUR}

Pada bagian ini dijelaskan beberapa penelitian terkait penerapan knowledge management dan faktor-faktor penentu outsourcing sistem informasi yang telah dilakukan oleh peneliti sebelumnya.

\section{A. Knowledge management (KM) pada outsourcing sistem informasi (SI)}

Pengetahuan (knowledge) menjadi sumber daya strategis yang signifikan bagi organisasi. Pengetahuan dapat didefinisikan sebagai informasi yang telah divalidasi melalui tes pembuktian [6]. Secara khusus, knowledge management diartikan sebagai proses menangkap, menyimpan, berbagi, dan menggunakan pengetahuan. KM merupakan faktor kunci untuk mendapatkan dan mempertahankan keunggulan kompetitif dalam proyek SI. Selanjutnya, pengetahuan merupakan bagian penting terutama dalam proyek outsourcing dengan omset dan kompleksitas yang tinggi.
Sistem Informasi adalah kegiatan yang menggunakan pengetahuan secara intensif. Baik praktisi dan peneliti telah lama mengakui kebutuhan untuk mengelola pengetahuan dan masyarakat bisa belajar dari komunitas knowledge management. Dari tinjauan sistematis pada 68 artikel tahun 1992-2006, knowledge management telah mendapatkan perhatian lebih dari para peneliti. Dari tinjauan literatur pada knowledge management dalam rekayasa perangkat lunak yang dilakukan, ditemukan bahwa kegiatan knowledge management khususnya penyebaran pengetahuan (knowledge sharing) dapat meningkatkan komunikasi dan pembelajaran [7]. Dalam studi sebelumnya, salah satu peneliti menyatakan bahwa pengetahuan merupakan faktor penting dalam keputusan outsourcing SI [8]. Sementara dalam studi yang dilakukan pada 2007, [9] ditemukan bahwa penyebaran dan transfer pengetahuan merupakan salah satu faktor penentu keberhasilan pelaksanaan outsourcing SI. Selain itu, penyebaran pengetahuan dipandang sebagai kesempatan untuk menciptakan pemahaman yang sama diantara para pemangku kepentingan yang terlibat dan untuk meningkatkan pengetahuan dari pihak lain dalam proyek [10]. Sementara itu, pembuatan pengetahuan (knowledge application) dan kerjasama, kemitraan dan/atau aliansi strategis saling melengkapi dalam konteks outsourcing SI [11].

\section{B. Penerapan knowledge management (KM)}

Penerapan Knowledge Management (KM) didefinisikan sebagai aktifitas organisasi yang terkait dengan knowledge management, termasuk akuisisi pengetahuan dan penciptaan, pengumpulan pengetahuan dan penyimpanan, penyebaran pengetahuan dan penerapan/penggunaan pengetahuan [12]. Aktifitas knowledge management dapat digambarkan sebagai siklus knowledge management. Dalkir [8] telah mengkategorikan siklus KM yang terintegrasi pada tiga tahap utama termasuk menangkap pengetahuan dan/atau penciptaan, penyebaran pengetahuan dan diseminasi, dan akuisisi pengetahuan dan penggunaan.

Pembuatan pengetahuan mengacu pada identifikasi dan kodifikasi (biasanya sebelumnya belum diketahui) pengetahuan internal yang ada dan pengetahuan dalam organisasi dan/atau pengetahuan eksternal dari lingkungan. Pembuatan pengetahuan adalah pengembangan pengetahuan baru dan inovasi know-how yang belum dimiliki sebelumnya oleh organisasi [8]. Dalam konteks proyek Sistem Informasi, pembuatan pengetahuan dipandang sebagai kegiatan untuk mengembangkan dan menyimpan pengetahuan baru termasuk mendiskusikan ide-ide baru, untuk menawarkan pendapat, saran serta berkomitmen untuk mendokumentasikan pengetahuan dan pengalaman. Selanjutnya, pertemuan tim, umpan balik tentang status proyek dan pengamatan bidang masalah juga termasuk didalamnya [6].

Dalam studinya, Lee [13] mendefinisikan berbagi pengetahuan sebagai kegiatan mentransfer atau menyebarkan pengetahuan dari satu orang, kelompok atau organisasi yang lain. Definisi ini secara luas mencakup pengetahuan tacit dan eksplisit. Namun, menurut Nonaka dan Takeuchi, pengetahuan tacit bersifat pribadi, berada pada konteks tertentu, sehingga membuatnya sulit untuk diresmikan, dikomunikasikan dan dibagikan kepada orang lain, sementara pengetahuan eksplisit dapat digambarkan sebagai pengetahuan yang menular di formal, bahasa yang sistematis. Lee [13] kemudian memperkenalkan konsep keterwakilan pengetahuan sebagai sejauh 
mana pengetahuan dapat dinyatakan dalam bentuk verbal, simbolis atau tertulis. Menurut pemikiran ini, pengetahuan tacit didefinisikan sebagai pengetahuan yang tidak dapat dinyatakan dalam bentuk verbal, simbolis dan ditulis sementara pengetahuan eksplisit adalah pengetahuan yang ada dalam bentuk simbolik atau tertulis. Kemudian, pengetahuan implisit adalah pengetahuan yang dapat dinyatakan dalam bentuk verbal, simbolis atau tertulis, tetapi belum diungkapkan.

Penggunaan pengetahuan (knowledge application) didefinisikan sebagai kegiatan menggunakan pengetahuan yang telah diserap atau dibuat [8]. Dalam konteks Sistem Informasi (SI), penggunaan pengetahuan dipandang sebagai kegiatan menggunakan pengetahuan yang telah diserap dan dibagi. Kegiatan ini termasuk penggunaan repositori pengetahuan dan fasilitas knowledge management system (KMS) dalam organisasi. Sejak penerapan pengetahuan dilakukan sebagai kegiatan untuk kembali menerapkan pengetahuan yang telah dibagikan baik implisit dan eksplisit [14], kolaborasi klien dan vendor untuk melakukan pencarian secara menyeluruh dari satu sumber dipandang sebagai salah satu cara untuk mempertahankan komunikasi melalui aplikasi dalam organisasi.

C. Faktor penentu kesuksesan outsourcing sistem informasi

Penentu kesuksesan outsourcing sistem informasi (SI) mengacu pada faktor-faktor yang mempengaruhi keberhasilan dari proses pembangunan proyek outsourcing sistem informasi [15]. Pada tahun 1990-an, banyak organisasi menetapkan bahwa hubungan erat dengan vendor mereka sebagai hasil dari kesulitan yang sebelumnya dialami oleh organisasi klien dalam mengelola hubungan mereka dengan vendor melalui kontrak formal [13]. Dalam penelitian ini kerjasama/kemitraan didefinisikan sebagai hubungan antarorganisasi untuk mencapai tujuan bersama. Penelitian sebelumnya mengenai outsourcing telah mengidentifikasi perjanjian antara klien dan vendor sebagai "aliansi" atau "kemitraan" [16], [17]. Di sisi lain, banyak studi menekankan pentingnya kerjasama/kemitraan pada outsourcing SI, di mana hal tersebut secara signifikan mempengaruhi keberhasilan outsourcing [4], [11], [13].

Grover, Cheon, dan Teng [11] menemukan bahwa indikator seperti kualitas kepercayaan, komunikasi, kepuasan, dan kerjasama yang signifikan dari kemitraan dapat membantu mencapai manfaat outsourcing. Pada penelitian lebih lanjut oleh Lee dan Kim [18] hipotesis Grover, Cheon, dan Teng [11] divalidasi dan ditemukan bahwa kepercayaan, pemahaman bisnis, pembagian manfaat dan risiko, konflik, dan komitmen, dipengaruhi oleh partisipasi, kualitas komunikasi, penyebaran informasi, lama hubungan, dan dukungan manajemen. Pentingnya hubungan dalam outsourcing didukung pula oleh Kern [4], di mana hubungan klien-vendor dilihat sebagai hal penting bagi perjanjian outsourcing.

Dalam model kerjasama/kemitraan yang diperkenalkan oleh Klepper [19] yang dikembangkan dari model hubungan antara klienvendor [20], terdapat beberapa sub-faktor yang yang berperan dalam pendalaman hubungan klien-vendor, yaitu daya tarik, komunikasi, norma-norma dan harapan. Dinyatakan bahwa hubungan akan baik jika terbuka, jujur dan komunikasi yang tepat waktu dalam pertukaran informasi keseharian antara klien dan vendor yang juga dapat dibangun melalui komunikasi sebagai sub-faktor hubungan. Sementara penelitian lebih lanjut, Lee dan Kim [4] dalam model untuk kualitas kerjasama/kemitraan juga menyebutkan kualitas komunikasi sebagai salah satu penentu kualitas kemitraan di mana saling melengkapi satu sama lain untuk mencapai keberhasilan outsourcing. Penelitian sebelumnya oleh Han [21] juga menemukan bahwa kualitas komunikasi sebagai proses interaksi positif mempengaruhi kualitas kemitraan melalui kepercayaan dan komitmen, dan memiliki hubungan langsung dengan keberhasilan outsourcing. Kualitas komunikasi disini didefinisikan sebagai akurasi, ketepatan waktu, kecukupan, dan kredibilitas informasi yang dipertukarkan [15].

\section{Usulan model penelitian}

Pengusulan model konseptual untuk penelitian ini mengintegrasikan model penelitian keberhasilan outsourcing dari penelitian sebelumnya [4], [15], [21]. Model yang digunakan dalam penelitian ini telah digunakan oleh beberapa peneliti, terutama untuk model kualitas kerjasama/kemitraan [13], [21-22].

Penelitian ini akan menggunakan model penentu keberhasilan outsourcing yang diyakini bahwa baik kualitas kemitraan dan kualitas komunikasi antara klien dan vendor mempengaruhi keberhasilan outsourcing. Organisasi dapat memperoleh keuntungan yang lebih tinggi dari outsourcing ketika mereka memiliki kerjasama yang lebih tinggi dengan vendor mereka dalam perjanjian outsourcing. Dimana organisasi juga percaya bahwa kualitas kemitraan termasuk komunikasi juga mempengaruhi kesuksesan outsourcing. Sementara kualitas komunikasi dan kualitas kemitraan saling melengkapi dalam konteks outsourcing SI. Dimana secara bersamaan pertukaran informasi dari hari ke hari antara klien dan vendor dengan kepercayaan, komunikasi terbuka dan tepat waktu dapat membawa seluruh pihak kepada hubungan yang lebih dekat. Untuk memahami hubungan antara kualitas komunikasi dan kualitas kerjasama/kemitraan pada keberhasilan outsourcing, set pertama hipotesis yang diajukan bahwa kedua variabel tersebut memiliki efek langsung pada keberhasilan outsourcing. Selain itu, kualitas komunikasi digambarkan memiliki hubungan langsung pada kualitas kemitraan. Akibatnya, set pertama hipotesis yang diajukan sebagai berikut:

H1: Kualitas komunikasi positif mempengaruhi tingkat keberhasilan outsourcing.

$\mathrm{H} 2$ : Kualitas kerjasama/kemitraan positif mempengaruhi tingkat keberhasilan outsourcing.

H3: Kualitas komunikasi positif mempengaruhi tingkat kualitas kerjasama/kemitraan.

Selanjutnya, penerapan Knowledge Management (KM) yang digambarkan sebagai suatu kegiatan pembuatan pengetahuan, penyebaran dan penggunaan dalam proyek outsourcing SI [8] dianggap sebagai enabler komunikasi yang dapat memperdalam hubungan klien-vendor [4], [11], [19], [22]. Kegiatan knowledge management yang digambarkan sebagai siklus knowledge management diperkirakan memiliki hubungan langsung dengan kualitas komunikasi dan kualitas kerjasama/kemitraan. Oleh karena itu, penelitian ini mengusulkan hipotesis berikut:

H4: Pembuatan pengetahuan (knowledge creation) positif mempengaruhi tingkat kualitas komunikasi. 
H5: Penyebaran Pengetahuan (knowledge sharing) positif mempengaruhi tingkat kualitas komunikasi.

H6: Penggunaan Pengetahuan (knowledge application) positif mempengaruhi tingkat kualitas komunikasi.

H7: Pembuatan pengetahuan (knowledge creation) positif mempengaruhi tingkat kualitas kerjasama/kemitraan.

H8: Penyebaran Pengetahuan (knowledge sharing) positif mempengaruhi tingkat kualitas kerjasama/kemitraan.

H9: Penggunaan Pengetahuan (knowledge application) positif mempengaruhi tingkat kualitas kerjasama/kemitraan.

Oleh karena itu, kombinasi model dari penelitian mengenai penerapan kowledge management (KM), kualitas komunikasi (Communication Quality), kualitas kemitraan (Partnership Quality) pada keberhasilan outsourcing SI (Outsourcing Success) digambarkan pada usulan model penelitian sebagai berikut:

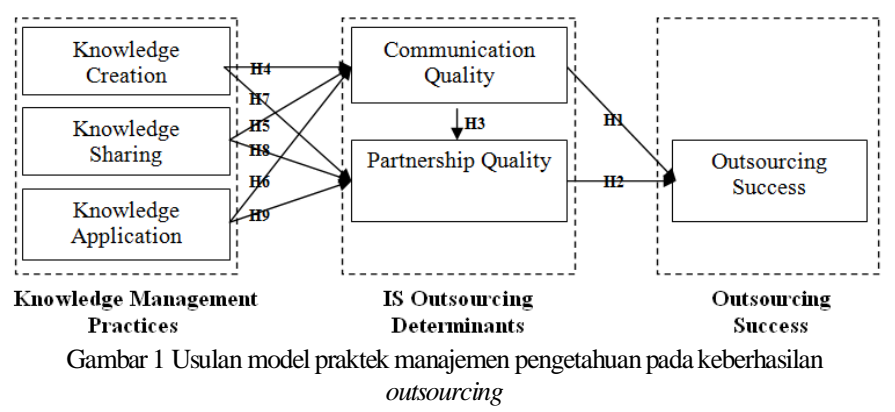

\section{METODOLOGI PENELITIAN}

\section{A. Pengembangan item pengukuran}

Pada penelitian ini, penentu kesuksesan outsourcing SI seperti kualitas kerjasama/kemitraan dan kualitas komunikasi diadopsi untuk menguji hubungan penerapan knowledge management terhadap keberhasilan outsourcing SI. Selain itu, penerapan knowledge management seperti pembuatan pengetahuan (knowledge creation); penyebaran pengetahuan (knowledge sharing) dan penggunaan pengetahuan (knowledge application) ditambahkan untuk membentuk model yang diusulkan berdasarkan penelitian sebelumnya di bidang yang sama. Penelitian kuantitatif melalui metode survey dengan menggunakan kuesioner dipilih untuk menganalisis data yang dikumpulkan dari manajer proyek yang pernah terlibat dalam proyek outsourcing SI untuk membuktikan hipotesis pada penelitian. Selain itu, karena pertanyaan yang digunakan dalam penelitian ini fokus pada kasus kontemporer, survei dianggap sebagai cara yang tepat untuk penelitian ini.

Unit analisis penelitian ini adalah hubungan antara klien dan vendor pada proyek outsourcing SI. Penelitian ini focus pada sudut pandang klien (perusahaan yang melakukan outsourcing) pada sektor telekomunikasi baik publik maupun swasta di Indonesia. Metode kuantitatif yang digunakan untuk menguji usulan model penelitian ini mengikuti metode yang digunakan oleh Lee [18] dalam pada penelitian sebelumnya. Pengembangan instrumen survei mempertimbangkan penelitian sebelumnya dengan konsep serupa. Pengukuran yang digunakan dalam kuesioner adalah metode multiple-item menggunakan skala lima poin dari 'sangat tidak setuju' hingga 'sangat setuju'. Instrumen survei yang digunakan mengadopsi sepenuhnya pengukuran dari penelitian sebelumnya [18], [24-25] dan mengkonversi definisi konstruksi ke dalam format kuesioner.

Penerapan knowledge management termasuk pembuatan pengetahuan (knowledge creation), penyebaran pengetahuan (knowledge sharing) dan penggunaan pengetahuan (knowledge application) sebagai variabel independen dalam model penelitian ini, mengacu pada kegiatan pengembangan pengetahuan baru, mentransfer atau menyebarluaskan pengetahuan dan menggunakan pengetahuan yang telah ditangkap atau dibuat. Hal ini mengacu kepada siklus penuh kegiatan knowledge management dalam proyek Outsourcing SI yang dilakukan. Untuk menguji penyebaran pengetahuan yang terbentuk dari pengetahuan baik itu eksplisit maupun implisit, instrumen yang diadopsi adalah instrument yang dikembangkan oleh Lee [18] dengan meninjau literatur sebelumnya mengenai penyebaran pengetahuan (knowledge sharing). Sementara itu, karena kurangnya literatur tentang pembuatan pengetahuan (knowledge creation) dan penggunaan pengetahuan (knowledge application) pada outsourcing SI. Instrumen untuk menguji pengaruh pada kedua variable tersebut dikonversi dari definisi konstruksi oleh peneliti sebelumnya [6], [14].

Kesuksesan outsourcing, sebagai variable dependen dari penelitian ini, mengacu pada keseluruhan keuntungan organisasi yang diperoleh dari outsourcing SI. Pelaksanaan outsourcing dimotivasi oleh manfaat strategis, ekonomis, dan teknologi [22]. Dengan demikian, keberhasilan outsourcing dapat dinilai dari segi pencapaian manfaat tersebut di atas. Untuk menangkap keuntungan dari outsourcing, instrumen berdasarkan studi Grover, Cheon dan Teng diadopsi untuk menilai tingkat pencapaian keuntungan strategis, ekonomis, dan teknologi pada pelaksanaan outsourcing [11]. Semua instrumen telah digunakan dan divalidasi oleh peneliti sebelumnya.

Sementara untuk kualitas kemitraan dan komunikasi, item yang dikembangkan oleh Lee dan Kim diadopsi [4]. Lee dan Kim [4] menganggap kualitas kemitraan (partnership quality) sebagai prediktor kunci keberhasilan outsourcing, dan mengidentifikasi lima faktor dari literatur tentang hubungan antar-organisasi dan kemitraan yang membentuk kualitas kemitraan: kepercayaan, pemahaman bisnis, manfaat dan risiko berbagi, konflik, dan komitmen. Sementara itu, kualitas komunikasi (communication quality) yang diukur dari akurasi, ketepatan waktu, kecukupan, dan kredibilitas pertukaran informasi diadopsi dari penelitian sebelumnya [21], [26]. instrumen kualitas komunikasi yang dikembangkan oleh Han [21] direvisi dari instrumen Mohrn [24] dan Lee [4] untuk menilai sejauh mana variabel-variabel ini mempengaruhi.

\section{B. Sampel dan pengukuran data}

Sektor telekomunikasi sebagai industri jasa dipilih berdasarkan tinjauan literatur yang dilakukan. Mary dan Lacity [15] menemukan 14 hubungan antara industri klien dan keberhasilan outsourcing SI, di mana dari 9 hubungan ditemukan bahwa jenis industri juga mempengaruhi. Loh dan Venkatraman [3] menggunakan istilah pelayanan dan industri untuk mengkategorikan jenis industri. Berdasarkan statistik pada informasi dan analisis industri outsourcing yang dilakukan oleh Ernst \& Young pada tahun 2008, ditemukan bahwa $28,5 \%$ industri yang melakukan outsourcing dimiliki oleh sektor industri seperti manufaktur, sedangkan bagian yang tersisa dari $71,5 \%$ dimiliki oleh sektor jasa termasuk keuangan, 
telekomunikasi, pemerintah dan transportasi. Sementara itu, statistik dari Wharton School dan universitas NY melaporkan bahwa persentase outsourcing oleh Industri paling banyak dilakukan oleh telekomunikasi dan layanan teknologi dengan besaran $42 \%$.

Kerangka sampling dari penelitian ini adalah 80 manajer proyek SI yang pernah terlibat dalam proyek-proyek outsourcing SI pada sektor telekomunikasi di Indonesia yang bertugas pada manajemen TI, pusat supply/divisi pengadaan. Kuesioner survei dikirim kepada 80 manajer proyek SI sebagaimana disebutkan di atas. Menurut Krejcie dan Morgan (1970) perhitungan ukuran sampel yang sesuai dengan ukuran populasi 80 adalah 66 sampel. Oleh karena itu, subjek penelitian ini terdiri dari 66 manajer proyek/supervisor/pemimpin tim dari sektor telekomunikasi di Indonesia, yang telah terlibat dalam proyek outsourcing SI pada rentang tahun 2012-2016.
Data dalam studi lapangan dikumpulkan dengan menggunakan 2 tahap. Pada tahap pertama, kuesioner didistribusikan melalui email kepada manajer proyek yang pernah terlibat dalam proyek outsourcing SI atau pengadaan. Dari 48 kuesioner yang disebarkan, hanya 42 kuesioner yang dikembalikan. Dikarenakan ukuran sampel yang sesuai bagi ukuran populasi 80 adalah 66 sampel, maka tahap kedua penyebaran kuesioner dilakukan untuk mencapai data 66 sampel. Pengumpulan data dalam tahap kedua dilakukan melalui email kepada 32 manajer proyek yang telah terlibat dalam proyek outsourcing atau pengadaan, data dikumpulkan dari sektor telekomunikasi publik. Dari 32 kuesioner yang disebarkan, 24 dikumpulkan. Dari kedua tahap pengumpulan data, 66 data yang lengkap dikumpulkan dan digunakan untuk menguji model. Karakteristik proyek dalam hal jenis proyek outsourcing SI yang dilakukan, periode kontrak (tahun), ukuran proyek (jumlah anggota proyek), dan anggaran (IDR) dirangkum dalam Tabel I.

TABELI

PROFIL PROYEK $(\mathrm{N}=66)$ [12][20]

\begin{tabular}{llllll}
\hline Tipe Proyek Outsourcing SI & Frekuensi & Persentase (\%) & Jumlah Anggota Proyek & Frekuensi & Persentase (\%) \\
\hline Pengembangan Aplikasi & 23 & $35 \%$ & Kurang dari 10 & 21 & $32 \%$ \\
Pemeliharaan Aplikasi & 6 & $9 \%$ & $10-20$ & 27 & $41 \%$ \\
Jaringan & 14 & $21 \%$ & $20-30$ & 12 & $18 \%$ \\
Konsultasi TI & 6 & $9 \%$ & Diatas 30 & 6 & $9 \%$ \\
Data centre & 7 & $11 \%$ & Tidak menjawab & 0 & $0 \%$ \\
Hardware & 5 & $8 \%$ & & Frekuensi & Persentase (\%) \\
Lain-lain & 5 & $8 \%$ & Anggaran (IDR) & $5 \%$ \\
Periode Kontrak (tahun) & Frekuensi & Persentase (\%) & Kurang dari 10,000,000 & 3 \\
Kurang dari 1 tahun & 14 & $21 \%$ & $10,000,000-50,000,000$ & 15 & $23 \%$ \\
1-3 tahun & 41 & $62 \%$ & $50,000,000-100,000,000$ & 12 & $18 \%$ \\
3-5 tahun & 9 & $14 \%$ & $100,000,000-500,000,000$ & 13 & $20 \%$ \\
Lebih dari 5 tahun & 2 & $3 \%$ & Di atas 500,000,000 & 23 & $35 \%$ \\
& & & & & \\
\hline
\end{tabular}

\section{Uji reliabilitas dan validitas}

Uji validitas dilakukan untuk memvalidasi item dalam kuesioner. Uji validitas pada penelitian ini dilakukan dengan melibatkan 2 manajer proyek dari sektor telekomunikasi dan 3 ahli untuk mengumpulkan pendapat serta pemahaman pengguna akhir dan para ahli dengan memeriksa pertanyaan-pertanyaan dalam kuesioner. Berdasarkan uji validitas yang dilakukan, pengguna akhir dan para ahli memberikan komentar mengenai pernyataan yang digunakan pada kuesioner. Studi percontohan juga dilakukan untuk menguji keandalan dari item yang digunakan dalam kuesioner dengan melibatkan 18 proyek manajer dari salah satu sektor telekomunikasi swasta di Jakarta, Indonesia. Dari umpan balik yang diberikan, kuesioner dilakukan perbaikan.

Sementara itu, konsistensi internal (Cronbach alpha) digunakan untuk menilai konsistensi dan keandalan semua item. Manurut Sekaran, nilai Cronbach Alpha yang diterima adalah diatas 0,60 [27]. Oleh karena itu, item-item yang memiliki nilai Cronbach Alpha rendah akan dihilangkan dari analisis lebih lanjut. Uji reliabilitas dilakukan dalam studi percontohan pada 18 orang staf manajemen TI di sektor telekomunikasi swasta di Jakarta, Indonesia. Karakteristik responden dalam uji pendahuluan mirip dengan karakteristik responden dalam penelitian ini. Untuk menentukan konsistensi internal pada item untuk setiap konstruksi, uji reliabilitas Cronbach Alpha dilakukan terhadap semua item dalam penelitian ini. Berdasarkan hasil pengujian terhadap nilai cronbach alpha, seluruh item dalam penelitian ini dapat digunakan dikarenakan nilai setiap item lebih tinggi dari 0,8 dan dapat digunakan untuk analisis lebih lanjut. Nilai alpha keseluruhan untuk semua item dalam penelitian ini adalah sangat tinggi dengan 0,965. Kesuksesan outsourcing memiliki nilai alpha tertinggi dengan 0,936. Di mana nilai reliabilitas item pada faktor penentu kesuksesan outsourcing SI cukup tinggi dengan 0,915 untuk kualitas kemitraan dan 0,895 untuk kualitas komunikasi. Sementara penerapan knowledge management yang terendah dengan nilai alpha 0,889 untuk penyebaran pengetahuan, 0,855 untuk pembuatan pengetahuan dan 0,844 untuk penggunaan pengetahuan. Berdasarkan hasil di atas nilai alpha keseluruhan untuk seluruh item lebih besar dari 0,8 dan nilai alpha dari masing-masing konstruk juga $>0,8$, ini berarti semua item dalam kuesioner konsisten, tidak ada item dikecualikan dan dapat digunakan pada studi lapangan.

\section{HASIL DAN ANALISIS}

Setelah menganalisis hubungan antar variabel, model penelitian yang dikembangkan berdasarkan hubungan antara penerapan manajemen pengetahuan, faktor penentu outsourcing dan kesuksesan outsourcing. Lima dari sembilan hipotesis yang dirumuskan dalam penelitian ini terbukti dengan menggunakan 66 data yang dikumpulkan. Berikut hasil dan diskusi dari model penelitian yang diusulkan. 
A. Analisis korelasi

Korelasi Pearson digunakan untuk menunjukkan arah, kekuatan dan signifikansi hubungan dalam penelitian ini. Dalam penelitian ini, interpretasi koefisien berdasarkan pada McBurney \& White [28]. Dalam penelitian ini kesuksesan outsourcing berkorelasi positif dengan kualitas komunikasi $(\mathrm{p}<0,01 ; \mathrm{r}>0,61)$ dan kualitas kemitraan $(\mathrm{p}<0,01 ; \mathrm{r}>0,61)$. Kualitas kemitraan berkorelasi positif dengan kualitas komunikasi $(\mathrm{p}<0,01 ; \mathrm{r}>0,61)$. Kualitas komunikasi berkorelasi positif dengan pembuatan pengetahuan $(p<0,01 ; r>0,41)$, penyebaran pengetahuan $(\mathrm{p}<0,01 ; \mathrm{r}>0,41)$, dan penggunaan pengetahuan $(p<0,01 ; r>0,61)$. Kualitas kemitraan berkorelasi positif dengan pembuatan pengetahuan $(\mathrm{p}<0,01 ; \mathrm{r}>0,21)$, penyebaran pengetahuan $(p<0,01 ; r>0,21)$, dan penggunaan pengetahuan $(p$
$<0,01 ; \mathrm{r}>0,41)$. Korelasi hasil untuk semua variabel digambarkan dalam Tabel II.

B. Analisis regresi berganda

Prosedur analisis regresi berganda digunakan untuk membangun pola hubungan antara variabel independen dan dependen dan sebagai hasil untuk menguji hubungan antar variabel. Beta dan Sig digunakan untuk menganalisis hasil dari teknik statistik pada regresi linear berganda. Tabel IV-Tabel VII menampilkan hasil regresi linier berganda antara kesuksesan outsourcing dan faktor penentu kesuksesan, kualitas kemitraan dan kualitas komunikasi, kualitas komunikasi dan variabel prediktor, dan kualitas kemitraan dengan variabel prediktor.

\begin{tabular}{|c|c|c|c|c|c|c|c|}
\hline \multicolumn{8}{|c|}{$\begin{array}{c}\text { TABELII } \\
\text { KORELASI }\end{array}$} \\
\hline & & $\mathrm{KC}$ & $\mathrm{KS}$ & KA & $\mathrm{CQ}$ & PQ & OS \\
\hline Knowledge Creation (KC) & Pearson Correlation & 1 & $.691 * *$ & $.697 * *$ & $.597 * *$ & $.403 * *$ & $.702 * *$ \\
\hline \multirow[t]{2}{*}{ Pembuatan Pengetahuan } & Sig. (2-tailed) & & .000 & .000 & .000 & .001 & .000 \\
\hline & $\mathrm{N}$ & 66 & 66 & 66 & 66 & 66 & 66 \\
\hline Knowledge Sharing (KS) & Pearson Correlation & $.691 * *$ & 1 & $.697 * *$ & $.557 * *$ & $.335 * *$ & $.586 * *$ \\
\hline \multirow[t]{2}{*}{ Penyebaran Pengetahuan } & Sig. (2-tailed) & .000 & & .000 & .000 & .006 & .000 \\
\hline & $\mathrm{N}$ & 66 & 66 & 66 & 66 & 66 & 66 \\
\hline Knowledge Application (KA) & Pearson Correlation & $.697 * *$ & $.697 * *$ & 1 & $.695^{* *}$ & $.606 * *$ & $.689 * *$ \\
\hline \multirow[t]{2}{*}{ Penggunaan Pengetahuan } & Sig. (2-tailed) & .000 & .000 & & .000 & .000 & .000 \\
\hline & $\mathrm{N}$ & 66 & 66 & 66 & 66 & 66 & 66 \\
\hline Communication Quality (CQ) & Pearson Correlation & $.597 * *$ & $.557 * *$ & $.695 * *$ & 1 & $.723 * *$ & $.654 * *$ \\
\hline \multirow[t]{2}{*}{ Kualitas Komunikasi } & Sig. (2-tailed) & .000 & .000 & .000 & & .000 & .000 \\
\hline & $\mathrm{N}$ & 66 & 66 & 66 & 66 & 66 & 66 \\
\hline Partnership Quality (PQ) & Pearson Correlation & $.403 * *$ & $.335^{* *}$ & $.606 * *$ & $.723 * *$ & 1 & $.710 * *$ \\
\hline \multirow[t]{2}{*}{ Kualitas Kemitraan } & Sig. (2-tailed) & .001 & .006 & .000 & .000 & & .000 \\
\hline & $\mathrm{N}$ & 66 & 66 & 66 & 66 & 66 & 66 \\
\hline Outsourcing Success (OS) & Pearson Correlation & $.702 * *$ & $.586 * *$ & $.689 * *$ & $.654 * *$ & $.710 * *$ & 1 \\
\hline \multirow[t]{2}{*}{ Kesuksesan Outsourcing } & Sig. (2-tailed) & .000 & .000 & .000 & .000 & .000 & \\
\hline & $\mathrm{N}$ & 66 & 66 & 66 & 66 & 66 & 66 \\
\hline
\end{tabular}

TABEL III

DESKRIPSIDAN KORELASI PADA PENGUKURAN VARIABEL

\begin{tabular}{lllllllllll}
\hline Variabel & $\mathrm{N}$ & Rataan & Std Dev & Alpha & KC & KS & KA & CQ & PQ & OS \\
\hline Knowledge creation (KC) & 66 & 4.378 & 3.256 & .855 & 1.0 & & & & \\
Knowledge sharing (KS) & 66 & 3.786 & 5.779 & .889 & $.691^{* *}$ & 1.0 & & & \\
Knowledge application (KA) & 66 & 4.000 & 3.642 & .844 & $.697^{* *}$ & $.697^{* *}$ & 1.0 & & \\
Communication quality (CQ) & 66 & 3.954 & 4.261 & .895 & $.597 * *$ & $.557^{* *}$ & $.695^{* *}$ & 1.0 & \\
Partnership quality (PQ) & 66 & 3.927 & 4.329 & .915 & $.403^{* *}$ & $.335^{* *}$ & $.606^{* *}$ & $.723^{* *}$ & 1.0 & \\
Outsourcing success (OS) & 66 & 4.003 & 5.426 & .936 & $.702^{* *}$ & $.586^{* *}$ & $.689^{* *}$ & $.654^{* *}$ & $.710^{* *}$ & 1.0 \\
\hline
\end{tabular}

TABELIV

REGRESILINEAR BERGANDA ANTARA KESUKSESANOUTSOURCING DANFAKTOR PENENTU KESUKSESAN(N=66)

\begin{tabular}{|c|c|c|c|c|c|c|c|}
\hline \multicolumn{8}{|c|}{ Dependent variable: Outsourcing Success } \\
\hline \multicolumn{8}{|c|}{$\mathrm{R} 2=.546$, adjusted $\mathrm{R} 2=.531, \mathrm{~F}=37.836, * \mathrm{p}<.05 ; * * \mathrm{p}<.01 ; * * * \mathrm{p}<.001$} \\
\hline \multirow[t]{2}{*}{ Model } & \multicolumn{2}{|c|}{ Unstandardized coefficients } & \multirow{2}{*}{$\begin{array}{l}\text { Standard } \\
\text { Beta }\end{array}$} & \multirow[t]{2}{*}{$\mathrm{T}$} & \multirow[t]{2}{*}{ Sig. } & \multicolumn{2}{|c|}{ Collinearity statistics } \\
\hline & B & Std. error & & & & Tolerance & VIF \\
\hline (Constant) & 10.952 & 3.069 & & 3.569 & .001 & & \\
\hline Communication Quality & .377 & .156 & $.296^{*}$ & 2.409 & .019 & .478 & 2.094 \\
\hline Partnership Quality & 621 & .154 & $.496 * * *$ & 4.035 & .000 & .478 & 2.094 \\
\hline
\end{tabular}

TABEL V

REGRESILINERA BERGANDA ANTARA KUALITAS KEMITRAANDAN KUALITAS KOMUNIKASI(N=66)

\begin{tabular}{|c|c|c|c|c|c|c|c|}
\hline \multicolumn{8}{|c|}{ Dependent variable: Partnership Quality } \\
\hline \multicolumn{8}{|c|}{$\mathrm{R} 2=.522$, adjusted $\mathrm{R} 2=.515, \mathrm{~F}=70.027, * \mathrm{p}<.05 ; * * \mathrm{p}<.01 ; * * * \mathrm{p}<.001$} \\
\hline \multirow[t]{2}{*}{ Model } & \multicolumn{2}{|c|}{ Unstandardized coefficients } & Standard & \multirow[t]{2}{*}{$\overline{\mathrm{T}}$} & \multirow[t]{2}{*}{ Sig. } & \multicolumn{2}{|c|}{ Collinearity statistics } \\
\hline & $\mathrm{B}$ & Std. error & Beta & & & Tolerance & VIF \\
\hline (Constant) & 3.232 & 2.457 & & 1.315 & .193 & & \\
\hline Communication Quality & .734 & .088 & $.036 * * *$ & 8.368 & .000 & 1.000 & 1.000 \\
\hline
\end{tabular}

Pengaruh Penerapan Knowledge Management (KM) terhadap Kesuksesan Pengadaan Sistem Informasi: 
TABEL VI

REGRESILINEAR BERGANDA ANTARA KUALITAS KOMUNIKASIDAN PREDICTOR VARIABLE (N=66)

\begin{tabular}{|c|c|c|c|c|c|c|c|}
\hline \multicolumn{8}{|c|}{ Dependent variable: Communication Quality } \\
\hline \multicolumn{8}{|c|}{$\mathrm{R} 2=.510$, adjusted $\mathrm{R} 2=.486, \mathrm{~F}=21.474, * \mathrm{p}<.05 ; * * \mathrm{p}<.01 ; * * * \mathrm{p}<.001$} \\
\hline \multirow[t]{2}{*}{ Model } & \multicolumn{2}{|c|}{ Unstandardized coefficients } & \multirow{2}{*}{$\begin{array}{l}\text { Standard } \\
\text { Beta }\end{array}$} & \multirow[t]{2}{*}{$\mathrm{T}$} & \multirow[t]{2}{*}{ Sig. } & \multicolumn{2}{|c|}{ Collinearity statistics } \\
\hline & $\mathrm{B}$ & Std. error & & & & Tolerance & VIF \\
\hline (Constant) & 5.299 & 3.234 & & 1.639 & .106 & & \\
\hline Knowledge Creation & .225 & .177 & .195 & 1.438 & .155 & .432 & 2.313 \\
\hline Knowledge Sharing & .047 & .100 & .063 & .468 & 642 & .432 & 2.313 \\
\hline Knowledge Application & .603 & .159 & $.515 * * *$ & 3.781 & .000 & .426 & 2.348 \\
\hline
\end{tabular}

TABEL VII

REGRESILINEAR BERGANDA ANTARA KUALITAS KEMITRAAN DAN PREDICTOR VARIABLES (N=66)

\begin{tabular}{|c|c|c|c|c|c|c|c|}
\hline \multicolumn{8}{|c|}{ Dependent variable: Partnership Quality } \\
\hline \multicolumn{8}{|c|}{$\mathrm{R} 2=.383$, adjusted $\mathrm{R} 2=.353, \mathrm{~F}=12.809, * \mathrm{p}<.05 ; * * \mathrm{p}<.01 ; * * * \mathrm{p}<.001$} \\
\hline \multirow[t]{2}{*}{ Model } & \multicolumn{2}{|c|}{ Unstandardized coefficients } & \multirow{2}{*}{$\begin{array}{l}\text { Standard } \\
\text { Beta }\end{array}$} & \multirow[t]{2}{*}{$\overline{\mathrm{T}}$} & \multirow[t]{2}{*}{ Sig. } & \multicolumn{2}{|c|}{ Collinearity statistics } \\
\hline & $\mathrm{B}$ & Std. error & & & & Tolerance & VIF \\
\hline (Constant) & 5.683 & 3.687 & & 1.542 & .128 & & \\
\hline Knowledge Creation & .047 & .202 & .036 & .234 & .816 & .432 & 2.313 \\
\hline Knowledge Sharing & -0.138 & .114 & -0.184 & -1.213 & .230 & .432 & 2.313 \\
\hline Knowledge Application & .843 & .182 & $.710 * * *$ & 4.640 & .000 & .426 & 2.348 \\
\hline
\end{tabular}

Berdasarkan hasil pengujian hubungan antara variabel dependen dan variabel independen dari model yang diusulkan dalam penelitian ini. 5 hipotesis dari 9 hipotesis terbukti, termasuk diantaranya hubungan antara faktor penentu outsourcing SI dan keberhasilan outsourcing itu sendiri. Sedangkan hubungan antara penerapan manajemen pengetahuan dan faktor penentu outsourcing SI hanya terbukti pada hubungan anatar pengembangan pengetahuan dan kualitas kemitraan serta kualitas komunikasi. Sementara hubungan antara pembuatan pengetahuan dan kualitas komunikasi, pembuatan pengetahuan dan kualitas kemitraan, penyebaran pengetahuan dan kualitas komunikasi serta penyebaran pengetahuan dan kualitas kemitraan tidak terbukti. Gambar 2 menampilkan ringkasan hasil pengujian hipotesis. Model ini dikembangkan berdasarkan hasil yang didapat menggunakan SPSS pada analisis faktor, korelasi dan uji regresi sehingga menghasilkan satu variabel independen, dua mediator dan satu variabel dependen seperti yang terlihat pada Gambar. 2.

\section{Diskusi}

Berdasarkan analisis regresi berganda yang dilakukan, lima hipotesis dapat diterima, di mana terbukti bahwa faktor yang penentu pada outsourcing SI dalam penelitian ini secara signifikan mempengaruhi tingkat keberhasilan dari outsourcing SI, yaitu berupa kualitas komunikasi (communication quality) dan kualitas kemitraan (partnership quality). Sementara itu, kualitas komunikasi juga terbukti memiliki hubungan yang signifikan dengan kualitas kemitraan. Namun penerapan knowledge management berupa pembuatan pengetahuan (knowledge creation), penyebaran pengetahuan (knowledge sharing), dan penggunaan pengetahuan (knowledge application) yang diperkirakan memiliki pengaruh yang signifikan terhadap penentu outsourcing SI dalam usulan model tidak sepenuhnya terbukti. Dimana hanya penggunaan pengetahuan (knowledge application) sebagai tahap akhir dalam siklus manajemen pengetahuan (knowledge management cycle) saja yang terbukti memiliki pengaruh yang signifikan dengan kualitas komunikasi dan kualitas kemitraan.
Dampak dari kualitas komunikasi dan kualitas kemitraan pada keberhasilan outsourcing SI telah diuji. Pada Tabel V, menunjukkan bahwa keduanya memiliki pengaruh yang signifikan terhadap keberhasilan outsourcing SI. Namun, kualitas kemitraan adalah prediktor terkuat kesuksesan outsourcing $(\beta=0,496, p<0,001)$, sementara kualitas komunikasi adalah prediktor lemah keberhasilan outsourcing berbanding dengan kualitas kemitraan $(\beta=0,296, p$ $<0,05)$. Lebih dari itu kualitas komunikasi terbukti sebagai prediktor yang dapat mempengaruhi tingkat kualitas kemitraan berdasarkan hasil Tabel V $(\beta=0,036, \mathrm{p}<0,001)$. Selanjutnya, hubungan pembuatan pengetahuan (knowledge creation), penyebaran pengetahuan (knowledge sharing) dan penggunaan pengetahuan (knowledge application) terhadap kualitas komunikasi dan kualitas kemitraan juga terbukti melalui penelitian ini

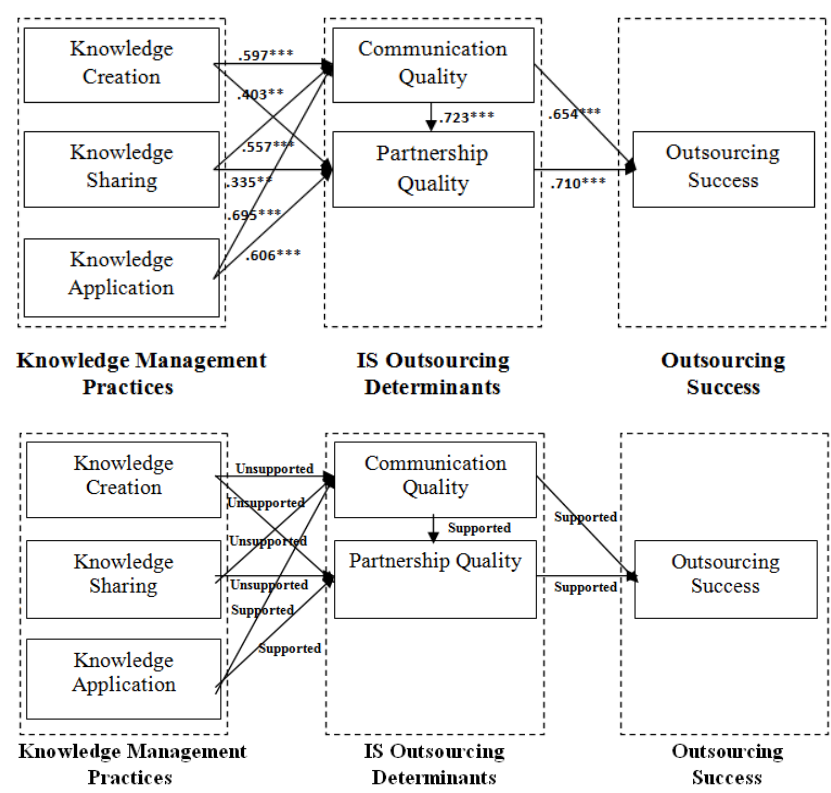

Gambar 2 Hasil model penelitian *** $*^{*}<.001 ; * * \mathrm{p}<.01 ; * \mathrm{p}<.05$ 
Hasil penelitian menunjukkan bahwa hanya penggunaan pengetahuan yang memiliki pengaruh terhadap kualitas komunikasi. Penggunaan pengetahuan merupakan prediktor kuat untuk kualitas komunikasi $(\beta=0,515, p<0,001)$. Sementara itu, hasil yang sama juga terlihat pada kualitas kemitraan, di mana hanya penggunaan pengetahuan yang memiliki pengaruh signifikan terhadap kualitas kemitraan. Penggunaan pengetahuan merupakan prediktor kuat bagi kualitas kemitraan $(\beta=0,710, \mathrm{p}<0,001)$ seperti yang terlihat pada Tabel VII.

Dalam penelitian ini, hanya penggunaan pengetahuan saja yang terbukti memiliki hubungan yang signifikan terhadap kualitas komunikasi dan kualitas kemitraan. Pada saat yang sama, kualitas komunikasi dan kualitas kemitraan adalah prediktor kuat bagi keberhasilan outsourcing SI. Dengan kata lain, penggunaan pengetahuan sebagai tahapan kunci dalam siklus manajemen pengetahuan (knowledge management cycle) sangat penting bagi keberhasilan outsourcing dan digambarkan memiliki hubungan tidak langsung untuk keberhasilan outsourcing melalui kualitas komunikasi dan kualitas kemitraan sebagai penentu keberhasilan outsourcing dalam model penelitian ini. Hal ini berbeda dengan hasil temuan pada penelitian sebelumnya yang menyatakan bahwa penyebaran pengetahuan sebagai faktor yang dapat mempengaruhi keberhasilan outsourcing melalui kualitas kemitraan sebagai mediator [13]. Lebih lanjut, terdapat beberapa peneliti lain yang membuktikan bahwa penyebaran informasi sebagai faktor yang mempengaruhi kualitas kemitraan [21], [4]. Hal tersebut terjadi karena perbedaan model yang diusulkan, dimana pada penelitian sebelumnya penyebaran pengetahuan dilihat sebagai variabel tunggal yang mempengaruhi keberhasilan outsourcing melalui mediator tertentu. Namun dalam penelitian ini, penyebaran pengetahuan dilihat sebagai bagian dari salah satu siklus lengkap dari manajemen pengetahuan. Seperti yang dibahas oleh Dalkir [8], siklus terpadu dari manajemen pengetahuan terkait satu sama lain, dimana proses dalam siklus manajemen pengetahuan dapat dikatakan sukses jika hasil dari aktifitas pembuatan pengetahuan dan penyebaran pengetahuan diimplementasikan dan digunakan ke dalam proses bisnis organisasi. Dinyatakan pula bahwa siklus manajemen pengetahuan akan berputar kembali saat orang-orang yang terlibat dalam aktifitas tersebut memahami dan memutuskan untuk menggunakan pengetahuan yang didapat. Dengan kata lain, penggunaan pengetahuan adalah langkah akhir dalam siklus manajemen pengetahuan di mana pengetahuan yang telah ditangkap, disebarkan dan kemudian dimanfaatkan dengan sebenarnya (dipergunakan). Jika langkah ini tidak dilakukan, semua upaya KM akan sia-sia, karena KM dapat berhasil hanya jika pengetahuan digunakan [8].

\section{KESIMPULAN}

Pengadaan (outsourcing) Sistem Informasi (SI) dipandang sebagai salah satu kegiatan yang dapat memberikan keuntungan strategis bagi organisasi. Sebaliknya, outsourcing tidak selalu memberikan keuntungan kepada organisasi, ketidak suksesan proyek outsourcing justru mendorong peningkatan biaya sebagai akibat dari perubahan bisnis dan memberikan dampak negatif pada strategi bisnis. Sebagian besar organisasi yang gagal dalam outsourcing dikarenakan kegagalan dalam berkomunikasi dan membangun hubungan dengan vendor mereka. Sangat tidak mudah untuk mencapai tujuan pada outsourcing SI, terdapat faktor-faktor yang perlu diperhitungkan guna mendapatkan keseluruhan keuntungan yang diperoleh dari outsourcing SI sehingga satu organisasi dapat dikategorikan berhasil dalam melakukan proyek outsourcing SI. Salah satu faktor yang perlu untuk dipertimbangkan untuk mencapai keberhasilan tersebut yaitu kualitas kemitraan (partnership quality) dan kualitas komunikasi (communication quality) yang telah terbukti dalam penelitian ini sebagai penentu yang mempengaruhi keberhasilan outsourcing. Organisasi perlu mempertimbangkan peningkatan kualitas komunikasi dan kualitas kemitraan saat melakukan outsourcing sebagai salah satu upaya untuk mencapai keberhasilan dalam outsourcing. Selain itu, dalam rangka untuk mencapai keberhasilan outsourcing, penggunaan pengetahuan (knowledge application) sebagai bagian dari siklus manajemen pengetahuan (knowledge management cycle) juga dapat dipertimbangkan sebagai salah satu faktor yang dapat membantu untuk mencapai kesuksesan outsourcing melalui peningkatan kualitas komunikasi dan kemitraan.

Penelitian ini memiliki beberapa keterbatasan seperti yang tercantum di bawah ini. Pertama, penelitian ini hanya mempelajari hubungan penerapan knowledge management bagi keberhasilan outsourcing SI melalui dua faktor, yang mana tidak menutup kemungkinan terdapatknya faktor lain sebagai penentu keberhasilan outsourcing SI. Kedua, penelitian hanya menggunakan sektor Telekomunikasi Indonesia untuk memvalidasi model, yang mungkin membatasi latar belakang sampel dan mempengaruhi hasilnya. Ketiga, perspektif yang digunakan pada penelitian ini hanya berdasarkan perspektif klien saja, dimana dimungkinkan untuk menggunakan perspektif vendor sebagai perbandingan. Terakhir, dari verifikasi model pada penelitian ini, dapat dilaksanakan penelitian lebih lanjut mengenai usulan framework guna menerapkan aktifitas knowledge management.

\section{UCAPAN TERIMA KASIH}

Penelitian ini dapat terlaksana dengan bantuan PPM Telkom University atas pendanaan Hibah Penelitian Dana Internal. Terima kasih diucapkan kepada manajer proyek dan staff pengadaan Sistem Informasi pada beberapa perusahaan telekomunikasi di Indonesia yang bersedia meluangkan waktu untuk berkontribusi pada pengumpulan data.

\section{DAFTAR PUSTAKA}

[1] Fowdar, C. D., \& Nagowah, S. D. (2012, 12-14 June 2012). Knowledge management practices in IT projectbased companies in an African country. Paper presented at the Computer \& Information Science (ICCIS), 2012 International Conference on.

[2] Schwalbe, K. (2010). Information Technology: Project Management: Course Technology Ptr.

[3] Loh, L., \& Venkatraman, N. (1992). Determinants of information technology outsourcing: a cross-sectional analysis. Journal of management information systems, 724. 
[4] Lee, J.-N., \& Kim, Y.-G. (1999). Effect of partnership quality on IS outsourcing success: conceptual framework and empirical validation. Journal of management information systems, 15(4), 29-61.

[5] Schwalbe, K. (2010). Information Technology: Project Management: Course Technology Ptr.

[6] Rus, I., \& Lindvall, M. (2002). Knowledge management in software engineering. Software, IEEE, 19(3), 26-38. doi: $10.1109 / \mathrm{ms} .2002 .1003450$

[7] Blumenberg, S., Wagner, H.-T., \& Beimborn, D. (2009). Knowledge transfer processes in IT outsourcing relationships and their impact on shared knowledge and outsourcing performance. International Journal of Information Management, 29(5), 342-352.

[8] Dalkir, K. (2013). Knowledge management in theory and practice: Routledge.

[9] Zhang, P., Zeng, Z.-X., \& Huang, C.-P. (2007, 21-25 Sept. 2007). Study on Critical Success Factors for IT Outsourcing Lifecycle. Paper presented at the Wireless Communications, Networking and Mobile Computing, 2007. WiCom 2007. International Conference on.

[10] Goo, J., Kishore, R., Rao, H., \& Nam, K. (2009). The role of service level agreements in relational management of information technology outsourcing: An empirical study. Mis Quarterly, 33(1), 119.

[11] Grover, V., Cheon, M. J., \& Teng, J. T. C. (1996). The effect of service quality and partnership on the outsourcing of information systems functions. $\mathrm{J}$. Manage. Inf. Syst., 12(4), 89-116.

[12] Akhavan, A., Owlia, M. S., Jafari, M., \& Zare, Y. (2011, 6-9 Dec. 2011). A model for linking knowledge management strategies, critical success factors, knowledge management practices and organizational performance; the case of Iranian universities. Paper presented at the Industrial Engineering and Engineering Management (IEEM), 2011 IEEE International Conference on.

[13] Lee, J.-N. (2001). The impact of knowledge sharing, organizational capability and partnership quality on IS outsourcing success. Information \& Management, 38(5), 323-335.

[14] Ward, J., \& Aurum, A. (2004). Knowledge management in software engineering-describing the process. Paper presented at the Software Engineering Conference, 2004. Proceedings. 2004 Australian.

[15] Lacity, M. C., Khan, S. A., \& Willcocks, L. P. (2009). A review of the IT outsourcing literature: Insights for practice. The Journal of Strategic Information Systems, 18(3), 130-146.

[16] Lacity, M. C., \& Willcocks, L. P. (1998). An Empirical Investigation of Information Technology Sourcing Practices: Lessons from Experience. Mis Quarterly, 22(3), 363-408.

[17] McFarlan, F. W., \& Nolan, R. L. (1995). How to manage an IT outsourcing alliance. Sloan management review, $36(2), 9-23$.
[18] Kern, T., \& Willcocks, L. (2000). Exploring information technology outsourcing relationships: theory and practice. The Journal of Strategic Information Systems, 9(4), 321-350.

[19] Klepper, R. (1993). The management of partnering development in I/S outsourcing. Paper presented at the System Sciences, 1993, Proceeding of the Twenty-Sixth Hawaii International Conference on.

[20] Dwyer, F. R., Schurr, P. H., \& Oh, S. (1987). Developing buyer-seller relationships. the Journal of Marketing, 11-27.

[21] Han, H.-S., Lee, J.-N., \& Seo, Y.-W. (2008). Analyzing the impact of a firm's capability on outsourcing success: A process perspective. Information \& Management, 45(1), 31-42.

[22] Lee, J.-N., Miranda, S. M., \& Kim, Y.-M. (2004). IT Outsourcing Strategies: Universalistic, Contingency, and Configurational Explanations of Success. Information Systems Research, 15(2), 110-131.

[23] Yang, L.-R., Chen, J.-H., \& Wang, H.-W. (2012). Assessing impacts of information technology on project success through knowledge management practice. Automation in Construction, 22(0), 182-191.

[24] Mohr, J., \& Spekman, R. (1994). Characteristics of partnership success: partnership attributes, communication behavior, and conflict resolution techniques. Strategic Management Journal, 15(2), 135152.

[25] Poppo, L., \& Zenger, T. (2002). Do formal contracts and relational governance function as substitutes or complements? Strategic Management Journal, 23(8), 707-725. doi: 10.1002/smj.249

[26] Henderson, J. C. (1990). Plugging into strategic partnerships: the critical IS connection. Sloan management review, 31(3), 7-18.

[27] Sekaran, U. (2006). Research methods for business: A skill building approach: Wiley. com.

[28] McBurney, D. H., \& White, T. L. (2009). Research methods: Cengage Learning. 